\title{
Reading Comprehension, Learning Strategies and verbal reasoning: Possible Relationships
}

\author{
Angélica Polvani Trassi ${ }^{1}$ \\ Katya Luciane de Oliveira ${ }^{1}$ \\ Amanda Lays Monteiro Inácio ${ }^{12}$ \\ ${ }^{1}$ Universidade Estadual de Londrina, Londrina, PR \\ ${ }^{2}$ Universidade São Francisco, Campinas, SP
}

\begin{abstract}
This article aimed to analyze the level of reading comprehension in elementary school students; to verify differences between school years for the Cloze test; investigate possible relationships between reading comprehension, learning strategies and verbal reasoning, and verifying whether verbal reasoning can predict the other variables. The participants were 470 students from grades 2 to 9 from the public network of a city in the north of Paraná, who answered the Cloze test and the Assessment Scale of Learning Strategies. Of the total sample, 45 students were selected to respond to the Wechsler Scale Verbal Scale of Abbreviated Intelligence. The sample presented a level of independent reading comprehension, and significant differences were found among students of the 2nd, 3rd and 4th years in comparison to the other school years. Statistically significant and positive correlations were obtained between the constructs, and the verbal reasoning showed to predict the other variables. Keywords: reading comprehension; learning strategies; verbal reasoning; elementary school
\end{abstract}

\section{Compreensão de Leitura, Estratégias de Aprendizagem e Raciocínio Verbal: Possíveis Relações}

\begin{abstract}
Resumo
Este artigo objetivou analisar o nível de compreensão de leitura em estudantes do ensino fundamental; verificar diferenças entre os anos escolares para o teste Cloze; investigar possíveis relações entre a compreensão de leitura, as estratégias de aprendizagem e o raciocínio verbal e verificar se o raciocínio verbal pode prever as demais variáveis. Participaram 470 alunos do $2^{\circ}$ ao $9^{\circ}$ anos provenientes da rede pública de uma cidade do norte do Paraná, que responderam ao teste Cloze e à Escala de Avaliação das Estratégias de Aprendizagem. Do total da amostra, foram selecionados 45 alunos para responder a Escala Verbal da Escala Wechsler de Inteligência Abreviada. A amostra apresentou nível de compreensão de leitura independente, sendo encontradas diferenças significativas entre estudantes do $2^{\circ}, 3^{\circ}$ e $4^{\circ}$ anos em comparação aos demais anos escolares. Foram obtidas correlações estatisticamente significativas e positivas entre os construtos, e o raciocínio verbal demonstrou prever as demais variáveis. Palavras-chave: compreensão de leitura, estratégias de aprendizagem, raciocínio verbal, ensino fundamental
\end{abstract}

\section{Comprensión Lectora, Estrategias de Aprendizaje e raciocinio verbal: Posibles Relaciones}

\begin{abstract}
Resumen
Este artículo tuvo por objetivo analizar el nivel de comprensión lectora en estudiantes de Enseñanza Primaria; verificar diferencias entre los años escolares para el test Cloze; investigar posibles relaciones entre comprensión lectora, estrategias de aprendizaje y razonamiento verbal y verificar si el mismo puede predecir las demás variables. Participaron 470 alumnos de $2^{\circ}$ a $9^{\circ}$ año provenientes de la red pública de una ciudad del norte de Paraná, que respondieron el test Cloze y la Escala de Evaluación de Estrategias de Aprendizaje. Del total de la muestra, se seleccionaron 45 alumnos para responder la Escala Verbal de la Escala Wechsler de Inteligencia Abreviada. La muestra presentó nivel de comprensión lectora independiente, encontrándose diferencias significativas entre los estudiantes de $2^{\circ}, 3^{\circ}$ y $4^{\circ}$ año comparados con los de los otros años. Se obtuvieron correlaciones estadísticamente significativas y positivas entre los constructos, y el razonamiento verbal demostró predecir las demás variables. Palabras clave: comprensión lectora; estrategias de aprendizaje; razonamiento verbal; Enseñanza Primaria
\end{abstract}

\section{Introduction}

A recurring complaint of parents, teachers and other professionals working in the field of education are the difficulties in reading and comprehension skills. Although the basic objectives of the National Curriculum Standards (PCN) (BRASIL, 1997) are that, throughout elementary school, the student acquires enough skills in Portuguese language that they will have full dominion of reading, writing, comprehension and essay writing, the studies by Baliza and Silva (2015), Boruchovitch (1999), Santos, Boruchovitch and Oliveira (2009) and Suehiro and Boruchovitch (2016) show that students haven't been reaching good levels of reading in the first years of schooling, being far below the levels that would be expected for the education stage in which they are.

Reading comprehension is a process in which the reader relates the different ideas arranged in the text and associates them with their previous knowledge 
(Oliveira, Santos, \& Rosa, 2016; Santos \& Fernandes, 2016). Thus, reading is an interaction between author and reader, intermediated by the text, encompassing several cognitive processes, such as language, memory, thought, perception and intelligence (Santos et al., 2009; Sternberg, 2010). Comprehensive reading encompasses both characteristics of the reader and of the text. Among the specific characteristics of the reader are: previous knowledge, goals and objectives, motivation and use of cognitive and metacognitive strategies, and among the characteristics of the text are: presentation, organization and content itself (Cunha \& Capellini, 2016; Santos et al., 2009).

According to Cunha, Silva and Capellini (2012) comprehension involves several related cognitive processes. Authors such as Fletcher, Lyons, Fuchs and Barnes (2009) and Soares and Emmerick (2013) investigated the cognitive and non-cognitive processes involved in reading comprehension. These authors' ideas will be presented next.

For Fletcher et al. (2009), text comprehension involves basic and higher cognitive processes. The basic processes are: decoding (the capacity to recognize and name words adequately); understanding of the meaning of the word syntax (knowledge and adequate use of the grammar rules); oral/hearing comprehension and working memory (type of memory that temporarily archives information and allows mental activities to be performed throughout time). Among the higher processes are: inferring (reading the information that is not explicit in the text); previous knowledge of the ideas in the text; metacognitive strategies (strategies connected to planning, monitoring and regulation of the behavior in comprehending the text) and sensitivity to the text structure (gender, organization of the information the author shows, among others) (Alcará \& Santos, 2015; Dembo, 1994; Scacchetti, Oliveira, \& Moreira, 2015; Soares \& Emmerick, 2013; Sternberg, 2010).

Students who have a good level of textual understanding show critical thinking, have a higher domain of the Portuguese language and have better school performance. In addition, they are able to easily identify the main ideas of the text, have a good perception of their comprehension and elaborate strategies for a better understanding of the content (Santos \& Ferraz, 2017; Santos et al., 2009). On the other hand, students with low level of reading comprehension have little knowledge of vocabulary, difficulty in extracting the meaning of words from the context of the text, problems expressing themselves verbally or in writing using the norm of the Portuguese language which was learned, have difficulties in critical thinking, problems integrating information and memory, lack of learning strategies and poor motivation to read (Sternberg, 2010).

Comprehensive reading requires a series of skills and procedures, one of which is the use of learning strategies. The learning strategies can be categorized in many different ways, however in this paper we will use a perspective based on the Theory of Information Processing, in which the learning strategies are seen as mental and behavioral actions and that aid the learning process through cognitive and metacognitive strategies that favor behavioral self-regulation, as well as a more effective learning (Boruchovitch, 1999; Dembo, 1994; Lima \& Santos, 2016; Inácio, Oliveira, \& Mariano, 2017).

Cognitive strategies involve procedures that favor the processes of learning, remembering and understanding certain information. Those can be either of three types: 1) essay (for example, copying a text in its literal form); 2) elaboration (paraphrasing, creating analogies and answering questions); and 3) organization (selecting main ideas, concept maps and schemas). Metacognitive strategies allow students to plan, monitor and regulate their thinking and behavior. They are divided into: 1) planning, when defining study goals; 2 ) monitoring, when the student monitors their understanding about a certain content; and 3) regulation, when the student follows up their performance and modifies learning strategies (Dembo, 1994; Scacchetti et al., 2015).

Effective learners use a wide variety of strategies, and also have greater responsibility over their learning processes, because they have high capacities to adapt to various school activities, their goals and needs. In addition, a successful student is one who makes use of more efficient strategies in order to access the knowledge he has stored. Thus, the use of learning strategies also contribute significantly to school success (Boruchovitch, 1999; Dembo, 1994; Inácio, 2016).

Based on the assumption that there are cognitive abilities involved in reading comprehension, we need to clarify the concept of intelligence and of verbal reasoning, since this is the cognitive process explored in this research. Sternberg (2010), through the Theory of Information Processing, understands intelligence as an ability to learn from experiences, developing strategies such as planning, monitoring and analyzing solutions for problems, based on metacognitive strategies. Thus, 
the speed and accuracy capacity to process information, the working memory, the resolution of analogies and of more complex problems involve intelligence. According to Wechsler (2004), intelligence is understood as a capacity of people to act effectively in their environment, being also multidetermined.

As for verbal reasoning, it is defined as a problem-solving skill related to the processing of verbal information, requiring that the individual express the knowledge acquired from their formal and informal learning. For this, it ranges from conceptual and abstract reasoning, deductive reasoning, verbal comprehension and expression, vocabulary knowledge and long-term verbal memory (for the subject to acquire, retain and retrieve this information) (Wechsler, 2013). Holdnack and Weiss (2016) point out that it is extremely important to retrieve information in verbal intelligence tasks.

Reading comprehension, learning strategies and intelligence can all be studied as contributing factors to academic success. Some researchers (Inácio, 2016; Mecca, Jana, Simoes, \& Macedo, 2015) have been concerned with conducting research correlating these variables, especially reading comprehension with nonverbal cognitive skills such as executive functions, selective attention and working memory .

However, there are few studies at the national level to specifically investigate the relationship between textual comprehension skills and verbal intelligence, such as those by Lima and Santos (2017) and Oliveira, Boruchovith and Santos (2013). Lima and Santos (2017) conducted a study with students from 6th to 9th grade, using the Cloze technique to evaluate reading comprehension and the Verbal Reasoning test of the Reasoning Test Battery (BPR-5). The authors found moderate correlations between both tests and a relationship between the constructs, meaning, the better the performance in verbal reasoning, the better was the reading comprehension. Oliveira et al. (2013) carried out a study with students from the 6th through 9th grades of the public elementary school system, using the Cloze test for comprehension reading and WISC-III for evaluation of verbal reasoning. The results showed statistically positive and significant correlation between the variables. Also according to Lima and Santos (2017), verbal reasoning can be an essential reading skill to facilitate the acquisition of the contents previously stored, as well as their understanding.

Therefore, comprehensive reading and learning strategies contribute to a more meaningful learning process, since they enable the student to store knowledge more efficiently and extract the meanings of the text adequately. However, it is necessary to understand what cognitive skills are involved in text comprehension. Based on this assumption, the objectives of this work were: to analyze the level of reading comprehension in elementary school students; to verify differences between school years within the Cloze test; investigate possible relationships between reading comprehension, learning strategies and verbal reasoning, and verifying whether verbal reasoning can predict the other variables.

\section{Method}

\section{Participants}

A total of 470 students from the 2nd through 9th grades of elementary school, from five public schools in a city in the north of Paraná participated in the study. Of these, 60\% $(n=283)$ were female and $40 \%(n=$ 187) male. The average age of the students was 10.7 years, being 7 years the minimum age and 15 years the maximum age.

\section{Instruments}

Cloze test (Taylor, 1953): a text, in which every fifth word is omitted and replaced by a trace of proportional size to the original word. The student must fill in the blanks with a word that he or she deems correct and that completes the meaning of the text. The Cloze test used in this work, based on the Cloze technique, is named The Princess and the Ghost (Santos, 2005), with 113 words and 15 omissions in total. The score is obtained from the sum of the correct answers in the Cloze test. Only one text was used, so that the test could discriminate the gradual evolution of students' scores over the school years. Next, the levels of reading comprehension were defined, being: frustration (up to $44 \%$ correct answers); instructional (scores varying from $44.1 \%$ to $57 \%$ ) and independent (above 57\%) (Bormuth, 1968). The text used shows evidence of content validity, as measured by three specialist judges and doctors in the area of linguistics.

Assessment Scale of Learning Strategies in Primary Education (EAVAP-EF) (see studies of validity in Oliveira, Boruchovitch, \& Santos, 2010): evaluates cognitive and metacognitive learning strategies (11 and 7 items, respectively) and the absence of dysfunctional metacognitive strategies (13 items) of children and adolescents, aged 7 to 16 , elementary school students. It has 31 items, arranged on a three-point Likert scale (always, sometimes, never). Its application can be individual or 
collective. It should be emphasized that the instrument is not for the exclusive use of psychologists.

Wechsler Abbreviated Scales of Intelligence (WASI) (evidence studies of validity in Wechsler, 2014): Briefly assesses the abilities in general, verbal and execution intelligences in 4 subtests: similarities, vocabulary, cubes, and matrix reasoning, the first two referring to the verbal area. This instrument is applied, individually, in people aged between 6 and 89 years. To meet the objectives of this work, only the verbal tests were applied, since they show greater relationship with reading comprehension due to the knowledge of words, abstract reasoning, inference, comprehension and oral expression. The instrument provides verbal, execution, and general intelligence quotient (IQ) scores. The possible classifications for IQ are: Extremely Low, Borderline, Lower Average, Average, Upper Average, Upper and Very High. It should be noted that this test may be used exclusively by psychologists.

\section{Data collection procedure}

After the participating institutions were approved, the project was referred to the university's Ethics Committee for Research with Human Beings - CEP, where the necessary authorizations for execution were obtained. Subsequently, collection times were scheduled with the institutions. The parents or guardians of the participating students signed the Informed Consent Term (TCLE). The data were collected collectively, in the classroom, with the Cloze and EAVAP-EF instruments, and individually with the WASI verbal tests. A sample of 45 students (5 students per school year) was drawn, at random, by the researcher and/or the participating institutions, once it was verified that the students had already answered the other tests. For the individual application, the spaces were provided by the institutions and the collections were previously scheduled with the intention of interfering as little as possible in the school routine.

\section{Data analysis}

The data were organized in spreadsheets and submitted to descriptive and inferential statistical analysis through the IBM SPSS Statistics for Windows ${ }^{\circledR}$ program, version 22.0. Initially we performed a frequency analysis to verify the mean, standard deviation and minimum and maximum scores obtained by the participants. Since the EAVAP-EF subscales presented different item numbers, for this scale we also extracted the weighted mean, in order to obtain a more reliable result. Subsequently, we used parametric tests, since the sample had a normal distribution, it would be more reliable under these conditions (Marôco, 2018). Thus, to investigate possible differences ANOVA and Tukey's post hoc test were performed, and also the Pearson correlation between scores to search for possible relations. Finally, with a simple linear regression analysis using the enter method we verified if the verbal reasoning can predict the other variables of the present study.

\section{Results}

The descriptive results of the Cloze Test, the EAVAP-EF and the WASI Verbal Scale will be presented below. Table 1 lists the average points of the sample participants for each test, as well as the standard deviation. For the EAVAP-EF, there is also the weighted average, since its subscales have different numbers of items.

Based on Table 1, it can be seen that the average score of the participants in the Cloze test was 10.27 (SD = 2.57), with a minimum score of 0 and a maximum score of 14 points. Thus, it is observed that the sample, in general, obtained a level of reading

Table 1.

Mean score, Standard Deviation and Weighted Average of Cloze test, Verbal Reasoning and Assessment Scale of Learning Strategies

\begin{tabular}{lccc}
\hline Measures & $\mathrm{M}$ & SD & Weighted Average \\
\hline Cloze & 10.27 & 2.57 & - \\
Verbal Reasoning & 91.28 & 13.53 & - \\
Lack of Dysfunctional Metacognitive Strategies & 15.60 & 4.94 & 1.2 \\
Cognitive Strategies & 8.64 & 3.96 & 0.78 \\
Metacognitive Strategies & 9.42 & 2.37 & 1.34 \\
General Score EAVAP-EF & 33.64 & 7.69 & 1.08 \\
\hline
\end{tabular}


comprehension equivalent to independent, according to Bormuth (1968). In addition, no participant was able to get the maximum score, which would be 15 points. As to verbal reasoning, the sample had an average Verbal IQ of 91.28 ( $\mathrm{SD}=13.53$ ), which is equivalent to the average score (Wechsler, 2013), with a minimum score of 65 (Extremely low) and the maximum score of 131 (Very High). This result may suggest that, in general, the students in this sample perform within expected verbal reasoning.

When we analyzed the weighted average of the subscales of the Scale of Assessment of Learning Strategies in Primary Education, we found that the participants performed better in Metacognitive Strategies (Weighted Average $=1.34$ ), followed by Absence of Dysfunctional Metacognitive Strategies (Weighted Average $=1.2$ ). However, the students showed lower performance in General Score (Weighted Average = 1.08) and in Cognitive Strategies (Weighted Average = 0.78). Thus, it can be hypothesized that the participants

Table 2.

Mean score and statistically significant differences between school grades at Cloze test

\begin{tabular}{|c|c|c|c|}
\hline \multicolumn{2}{|c|}{ Grade } & \multirow{2}{*}{$\begin{array}{c}M \\
7.16\end{array}$} & \multirow[t]{2}{*}{$p$} \\
\hline $2 \mathrm{nd}$ & & & \\
\hline & $3 \mathrm{rd}$ & 8.72 & 0.029 \\
\hline & 4th & 9.08 & 0.003 \\
\hline & 5 th & 11.14 & 0.000 \\
\hline & 6th & 10.89 & 0.000 \\
\hline & 7 th & 10.55 & 0.000 \\
\hline & 8th & 11.61 & 0.000 \\
\hline & 9th & 11.44 & 0.000 \\
\hline \multirow[t]{6}{*}{$3 \mathrm{rd}$} & & 8.72 & \\
\hline & 5th & 11.14 & 0.000 \\
\hline & 6th & 10.89 & 0.000 \\
\hline & 7th & 10.55 & 0.000 \\
\hline & 8th & 11.61 & 0.000 \\
\hline & 9th & 11.44 & 0.000 \\
\hline \multirow[t]{6}{*}{ 4th } & & 9.08 & \\
\hline & 5 th & 11.14 & 0.000 \\
\hline & 6th & 10.89 & 0.001 \\
\hline & 7th & 10.55 & 0.017 \\
\hline & 8th & 11.61 & 0.000 \\
\hline & 9th & 11.44 & 0.000 \\
\hline
\end{tabular}

of the research show more self-monitoring strategies of their learning and, in turn, have little knowledge of diversified study strategies.

The study also sought to analyze possible differences between the school years in reading comprehension, for which the Analysis of Variance - ANOVA - was used. Table 2 indicates only the statistically significant results between the school years for the Cloze test.

Table 2 indicates the difference in performance of reading comprehension level of elementary school students, considering $\mathrm{F}(7.467)=23.252, \mathrm{p}=0.000$. It was verified that the students of the 2 nd year $(\mathrm{M}=$ 7.16) showed a mean score lower than the students of the 3rd $(M=8.72)$, 4th year $(M=9.08), 5$ th $(M=11$, 14), 6th $(\mathrm{M}=10.89), 7$ th $(\mathrm{M}=10.55)$, 8th $(\mathrm{M}=11$, 61) and 9th years $(M=11.44)$. This suggests that this year (2nd) has a worse level of reading comprehension compared to the others. In the same way, students of the 3rd $(M=8.72)$ and 4th grades $(M=9.08)$ obtained average scores lower in relation to 5 th $(\mathrm{M}=11,14)$, 6th $(M=10,89), 7$ th $(M=10.55), 8$ th $(M=11,61)$ and 9th grades $(M=11.44)$. Thus, the data allows us to infer that students in grades 5 to 9 presented a higher score than students in grades 2, 3 and 4, and no statistically significant differences were found between the years of middle school.

The research also sought to find a relationship between reading comprehension, learning strategies and verbal reasoning. For this, the Pearson correlation was used. Statistically significant and positive correlations were obtained between the Cloze test and metacognitive strategies $(r=0.217, p<0.001)$. This result supposedly shows that the higher the level of reading comprehension a child has, the more metacognitive strategies she tends to use. However, in submitting this data to the linear regression analysis, to verify the hypothesis that reading comprehension would predict the use of metacognitive strategies at the time of learning, it could not be confirmed, indicating that there is no prediction in this sample.

A correlation was also established between the Cloze test and verbal IQ ( $r=0.528$; $\mathrm{p}<0.001)$, that is, hypothetically, the higher the verbal reasoning of a person, the better their level of reading comprehension. Likewise, the hypothesis that verbal IQ could predict reading comprehension was tested in regression analysis, and the data are presented in Table 3.

It can be seen in Table 3 that the verbal IQ of the sample could predict reading comprehension by approximately $25 \%$. Thus, it seems that the student's 
Table 3.

Linear regression for Cloze

\begin{tabular}{lcccccc}
\hline Independent Variable & $\mathrm{R}$ & $\mathrm{R}^{2}$ adjusted & $F$ & Betaz & $t$ & $p$ \\
\hline Verbal IQ & 0.528 & 0.254 & $(1.285)=10.850$ & 0.528 & 0.394 & 0.003 \\
\hline
\end{tabular}

reading comprehension depends to some extent on their verbal reasoning.

Finally, we reached a relationship between the verbal IQ and the metacognitive strategies subscale $(\mathrm{r}=0.347 ; \mathrm{p}<0.001)$. Thus, it seems, the greater the student's verbal intelligence, the more metacognitive strategies he uses to learn. Again through the regression analysis we sought to verify if the IQ could predict the use of metacognitive strategies. Table 4 presents the results found.

According to Table 4, it can be observed that verbal IQ can predict the metacognitive strategies used in the school context in approximately 10\%. Thus, the monitoring and regulation of one's own thinking, characteristic to metacognitive strategies, depends to some extent on the student's verbal reasoning.

\section{Discussion}

From the results presented, it can be observed that the sample obtained in the Cloze test, in average, scores corresponding to the level denominated independent, according to the classification of Bormuth (1968). This result indicates that participants tend to easily identify the main ideas of the text, have a disposition to a more critical thinking, good dominion of the Portuguese language, and a good reading comprehension (Santos, et al. 2009). In addition, it can be said, as already indicated by Santos and Fernandes (2016), that a good level of reading comprehension has been a predictor of better academic abilities, and, therefore, of a good school performance.

On the differences between the school years for the comprehension of text, we observed that students of the 2 nd $(M=7.16), 3 \mathrm{rd}(\mathrm{M}=8.72)$ and 4th years
$(\mathrm{M}=9.08)$ scored less than students of other school years, suggesting a level of reading comprehension equivalent to frustration, according to Bormuth's (1968) criteria and thus indicating more difficulty in this ability. On the other hand, students in grades 5 to 9 showed a reading comprehension level classified as independent, that is, they could more easily understand the content read, use reading strategies, including inferences, to relate the ideas of the text to their knowledge, as well as may have better school performance (PCNs, 1997; Soares \& Emmerick, 2013). The data is similar to the study by Oliveira, Trassi, Santos and Cunha (2017), who identified an increase in the level of reading comprehension during the school years, when students in the 1 st and 2 nd years obtained a frustration level, the $3 \mathrm{rd}$ and 4 th years, instrumental level, and from the 5 th year on, independent level of textual comprehension.

Thus, the results confirm the findings of the scientific literature on the subject (Cunha \& Capellini, 2016; Cunha, Martins, \& Capellini, 2017, Oliveira et al., 2017; Pacheco \& Santos, 2017; Lúcio, Lima, Jesuino, \& Rueda, 2018), who identified that students of more advanced years and, therefore, with more schooling, have better score in the Cloze test and, consequently, better level of reading comprehension.

Some authors (Morais, Leite, \& Kolinsky, 2013; Pacheco \& Santos, 2017) explain that the difference in level of reading comprehension between school years is understood by changes in reading abilities over time. Thus, initially the reading ability is based only on the recognition of written words, then the child must identify the words with precision and speed and, finally, identify most of the words written automatically, which makes a more fluent reading than before. In this way,

Table 4.

Linear regression for metacognitive strategies

\begin{tabular}{lcccccc}
\hline Independent Variable & $\mathrm{R}$ & $\mathrm{R}^{2}$ adjusted & $F$ & Betaz & $t$ & $p$ \\
\hline Verbal IQ & 0.347 & 0.100 & $(1.285)=5.067$ & 0.347 & 2.251 & 0.030 \\
\hline
\end{tabular}


readers in the process of schooling take more time to perform the complex operations implied in a good understanding of a text. Thus, we can hypothesize that students in grades 5 to 9 presented a more satisfactory performance in reading comprehension, because they already have a better mastery of the skills, while students in grades 2 to 4 do not.

To date, only the study by Oliveira et al. (2017) was aimed at comparing the level of reading comprehension throughout the entire elementary school phase. Most of the researches (Faria et al., 2015, Oliveira et al., 2013, Santos \& Ferraz, 2017; Silva et al., 2015) is intended to investigate this variable in some years, which limits the comparison for this school period. This result is outstanding, since Suehiro (2013) investigated the Brazilian scientific production on the technique of Cloze, between the years of 2002 and 2012. Out of the 32 articles found on the subject, most studies were held with elementary school students, followed by higher education and later with high school. Thus, there are still gaps in the research to investigate the differences between school years throughout this stage of schooling. This fact is pertinent, as the reading comprehension assists in the construction of critical thinking and in the understanding of school knowledge, especially in elementary school, where this ability can be extended to subsequent levels and modalities of teaching (Oliveira, et al., 2016).

One limitation of this study was the use of a single text for the entire sample in order to investigate reading comprehension. As a consequence, there is the possibility that the students of the most advanced years (5th to 9th grade) have considered the activity easy. In addition, the instrument may not have been able to discriminate more effectively the difference in the reading ability of students of all evaluated years. Therefore, it is suggested that two texts be used in the Cloze format to meet the characteristics of the entire elementary school age group.

As to the correlation found between the metacognitive strategy and the Cloze test, this result was shown by Fletcher et al (2009), Joly and Dias (2012), Lima and Santos (2016) and Soares and Emmerick ( 2013). However, similarly to the study by Lima and Santos (2016) the result was not confirmed in the regression analysis, and it was not possible to verify if one variable could predict the other. In this sense, it would be important for new studies to be performed, with a larger number of subjects, to complement the data that was previously found.
A statistically significant correlation was also obtained between verbal IQ and reading comprehension. In addition, verbal IQ has been shown to predict student reading comprehension (by $25 \%$ ). Having said this, it can be inferred that the higher the verbal IQ of a student, the better his level of textual comprehension. This result is supported by Lima and Santos (2017) and Oliveira et al. (2013) who found correlations between verbal reasoning and textual comprehension. It should be emphasized that verbal reasoning encompasses the processing of information of the verbal type, knowledge of vocabulary, verbal comprehension and expression (Wechsler, 2013), among others, that is, all the skills found in reading comprehension activities.

It is also worth noting that although the sample to evaluate verbal reasoning was relatively small and that the other studies used WISC-III as an intelligence measure, the WASI was also sensitive to identify the correlation with comprehensive reading. One thing to consider is that the researchers have identified other possible cognitive abilities as contributors to the reading comprehension process. Therefore, it is recommended that studies are carried out, to investigate the association between cognitive processes and text comprehension, with an increase in the sample for verbal intelligence.

Finally, statistically significant correlations were achieved between verbal IQ and metacognitive strategies. Thus, verbal IQ has been shown to predict the use of students' metacognitive strategies to some extent (by 10\%). These results corroborate with the research by Joly and Dias (2012), who also found an association between these variables in primary school samples, indicating that the greater the child's ability to solve verbal problems, the more aware they are of their cognitive and learning processes. In this regard, Sternberg (2010) points out that children with metacognitive deficits have poor academic performance, since they are not aware of their mental processes, have difficulty thinking in different ways in order to solve problems and do not monitor their own behaviors.

Considering the above, it is clear that the study was able to meet its objectives, to raise the level of reading comprehension, to evaluate the differences between the school years and to seek correlations between the variables. It is believed that this work contributed to the assessment of the level of reading comprehension throughout the elementary school stage. In addition, students with learning difficulties would benefit from the identification of children with lower levels of 
reading comprehension, since the lack of mastery in this ability can lead to significant difficulties in several other academic areas.

However, it is recommended that other studies are carried out with different population characteristics, especially with high school, since it is the school period with the least amount of research on this subject. When talking about elementary education, we suggest that there should be greater investment in studies that investigate reading comprehension in students in grades 2 to 9 , related to other psychoeducational variables that interfere with school success, such as a measure of academic performance, motivation in school and other cognitive processes linked to reading comprehension.

\section{References}

Alcará, A. R., \& Santos, A. A. A. (2015). Avaliação e desenvolvimento da compreensão de leitura em universitários. Estudos de Psicologia (Campinas), 32(1), 63-73. doi: 10.1590/0103-166X2015000100006

Baliza, A. A., \& Silva, D. V. (2015). Avaliação da compreensão de leitura em estudantes do ensino fundamental. Lumen: Educare, 1(1), 93-114. doi: 10.19141/2447-5432/lumen.v1.n1.p.93-114

Bormuth, J. R. (1968). Cloze test readability: criterion reference scores. Journal of Educacional Measurement, 5(3), 189-196. doi: https:/ / doi.org/10.1111/j.1745-3984.1968.tb00625.x

Brasil. (1997). Secretaria de Educação Fundamental. Parâmetros curriculares nacionais: língua portuguesa. Brasília. Retrieved from: http://portal.mec.gov. $\mathrm{br} / \mathrm{seb} /$ arquivos/pdf/livro02.pdf

Boruchovitch, E. (1999). Estratégias de aprendizagem e desempenho escolar: considerações para a prática educacional. Psicologia: Reflexão e Crítica, 12(2), 361376.doi: 10.1590/S0102-79721999000200008

Cunha, V. L. O., \& Capellini, S. A. (2016). Caracterização do desempenho de escolares do $3^{\circ}$ ao $5^{\circ}$ ano do ensino fundamental em compreensão de leitura. Revista CEFAC, 18(4), 941-951. doi: 10.1590/1982-0216201618421215

Cunha, V. L. O., Martins, A., \& Capellini, S. A. (2017). Relação entre fluência e compreensão leitora em escolares com dificuldades de aprendizagem. Psicologia: Teoria e Pesquisa, 33, 1-8. doi: http://dx.doi. org $/ 10.1590 / 0102.3772 \mathrm{e} 33314$
Cunha, V.L., Silva, C., \& Capellini, S. A. (2012). Correlação entre habilidades básicas de leitura e compreensão de leitura. Estudos de Psicologia (Campinas), 29, 799807. doi: 10.1590/S0103-166X2012000500016

Dembo, M. H. (1994). Applying educational psychology. New York: Longman.

Faria, R.L. etal. (2015). Análise da compreensão de leitura em texto de ciências com alunos do $5^{\circ}$ ano do ensino fundamental. Enciclopédia Biosfera, 11(20), 132-138. Retrieved from: https://www.researchgate.net/ publication/275152488_ANALISE_DA_COMPREENSAO_DE_LEITURA_EM_TEXTO_ DE_CIENCIAS_COM_ALUNOS_DO_5_ ANO_DO_ENSINO_FUNDAMENTAL

Fletcher, J. M., Lyon, G. R., Fuchs, L.S., \& Barnes, M. A. (2009). Transtorno da leitura: compreensão. In J. M. Fletcher; G. R. Lyon; L. S. Fuchs, \& M. A. Barnes (Eds.). Transtornos de aprendizagem: da identificação à intervenção (pp 197-222). São Paulo: Artmed.

Fonseca, J. D. et al. (2015). Avaliação da compreensão leitora no ensino fundamental. Enciclopédia Biosfera, 11(20), 240-246. Retrieved from: http://www. conhecer.org.br/enciclop/2015a/avaliacao $\% 20$ da $\% 20$ compreensao $\% 202 . p d f$

Holdnack, J. A., \& Weiss, L. G. (2016). Fundamentos da Interpretação do WISC-IV Integrated. In L. G. Weiss, D. H. Saklofske, A. Prifitera, \& J. A. Holdnack. WISC-IV - Interpretação Clínica Avançada (pp.194-213). São Paulo: Pearson.

Inácio, F. F. (2016). Memória, estilos intelectuais e estratégias de aprendizagem:estudando os transtornos do neurodesenvolvimento em alunos do ensino fundamental e percepção de seus professores. (Dissertação de mestrado em Educação). Universidade Estadual de Londrina, Paraná, Brasil.

Inácio, F. F., Oliveira, K. L., \& Mariano, M. L. S. (2017). Estilos intelectuais e estratégias de aprendizagem na percepção de professores do ensino fundamental. Psicologia Escolar e Educacional, 21(3), 447-455. doi: 10.1590/2175-3539/2017/021311171

Joly, M. C. R. A., \& Dias, A. S. (2012). Metacompreensão e inteligência: um estudo correlacional com estudantes do ensino fundamental. Estudos de Psicologia (Natal), 17(1), 43-52. doi: 10.1590/ S1413-294X2012000100006 
Lima, T. H., \& Santos, A. A. A. (2016). Compreensão de leitura e o uso de Estratégias de aprendizagem: estudo correlacional. Argumentos Pró-Educação, 1(1), 103-117. doi: 10.24280/ape.v1i1.64

Lima, T. H, \& Santos, A. A. A. (2017). Compreensão de leitura e sua relação com raciocínio verbal. In S. G. Caliatto, S. M. S. S. Oliveira, N. B. Cunha, \& M.C.R.A. Joly (Eds.). Avaliação: diferentes processos no contexto educacional (pp.101-116). Uberlândia, Navegando Publicações.

Lúcio, P. S., Lima, T. H., Jesuíno, A. D. S. A., Rueda, F. J. M. (2018). Compreensão de leitura e consciência morfológica em crianças do ensino fundamental. Estudos Interdisciplinares em Psicologia, 9(3), 112-131. doi: 10.5433/2236-6407.2018v9n3suplp112

Marôco, J. (2018). Análise Estatística com o SPSS Statistics. ReportNumber, $7^{\mathrm{a}} \mathrm{ed}$.

Mecca, T. P., Jana, T. B., Simões, M. R., \& Macedo, E. C. (2015). Relação entre habilidades cognitivas não-verbais e variáveis presentes no contexto educacional. Psicologia Escolar e Educacional, 19(2), 329-340. doi: 10.1590/2175-3539/2015/0192844

Morais, J., Leite, I., \& Kolinsky, R. (2013). Entre a pré-leitura e a leitura hábil: condições patamares da aprendizagem. In M. R. Maluf, \& C. Cardoso-Martins (Eds.), Alfabetização no século XXI: como se aprende a ler e a escrever (pp.17-48). Porto Alegre.

Oliveira, K. L., Boruchovitch, E, \& Santos, A. A. A. (2010). Escala de Avaliação das Estratégias de Aprendizagem para o Ensino Fundamental - EAVAP-EF. São Paulo: Casa do Psicólogo.

Oliveira, K. L., Boruchovitch, E., \& Santos, A. A. A. (2013). Compreensão de leitura e coeficiente intelectual verbal. In M. M. P. E. Mota, \& A. Spinillo. Compreensão de textos (pp. 123-136). São Paulo: Casa do Psicólogo.

Oliveira, K. L., Santos, A. A. A., \& Rosa, M. T. (2016). Compreensão em Leitura no Ensino Fundamental. Psicologia: Ciência e Profissão, 36(3), 546-557. doi: 10.1590/1982-3703001172014

Oliveira, K. L., Trassi, A. P., Santos, A. A. A., \& Cunha, N. B (2017). Teste de Cloze no Ensino Fundamental: evidências de validade de critério. Psicologia da Educaşão, 45, 35-44. doi: 10.5935/2175-3520.20170015

Pacheco, V., Santos, A. J. (2017). A fluência e compreensão leitora em diferentes níveis de escolaridade. Confluência, 52, 232-256. doi: http:// dx.doi.org/10.18364/rc.v1i52.172

Santos, A. A. A. (2005). O Teste de Cloze como instrumento de diagnóstico da compreensão de leitura. Relatório Técnico. Itatiba: Universidade São Francisco.

Santos, A. A. A., \& Fernandes, E. S. O. (2016). Habilidade de escrita e compreensão de leitura como preditores de desempenho escolar. Psicologia Escolar e Educacional, 20(3), 465-473. doi: 10.1590/2175-3539/2015/02031013

Santos, A. A. A., \& Ferraz, A. S. (2017). Avaliação de habilidades relacionadas à compreensão de leitura no ensino fundamental. Psico (Porto Alegre), 48(1), 21-30. doi: 10.15448/1980-8623.2017.1.24376

Santos, A. A. A., Boruchovitch, E., \& Oliveira, K. L. (2009). Cloze: um instrumento de diagnóstico e intervenção. São Paulo: Casa do Psicólogo.

Scacchetti, F. A. P., Oliveira, K. L., \& Moreira, A. E. C. (2015). Estratégias de Aprendizagem no Ensino Técnico Profissional. Psico-USF, 20(3), 433-446. doi: 10.1590/1413-82712015200306

Silva, L. C. et al. (2015). Compreensão leitora na disciplina de ciências em alunos do $6^{\circ}$ ano do ensino fundamental. Enciclopédia Biosfera, 11(20), 854-861. Retrieved from: http://www.conhecer.org.br/ enciclop/2015a/compreensao\%20leitora.pdf

Soares, A. B., \& Emmerick, T. A. (2013). Compreensão de textos: processos e modelos. In M. M. P. E. Mota, \& A. Spinillo. Compreensão de textos (pp. 13-36). São Paulo: Casa do Psicólogo.

Suehiro, A. C. B. (2013). Produção científica sobre o teste de Cloze. Psicologia Escolar e Educacional, 17(2), 223-232. doi: 10.1590/S1413-85572013000200004

Suehiro, A. C. B., \& Boruchovitch, E. (2016). Compreensão em Leitura em Estudantes do Terceiro e Quarto Ciclos do Ensino Fundamental. Psico-USF, 21(3), 561-572. doi: 10.1590/1413-82712016210310

Sternberg, R. J. (2010). Psicologia cognitiva. Porto Alegre: Artmed.

Taylor, W. L. (1953). Cloze procedure: A new tool for measuring perspective on the discourse. Journalism Quarterly, 30(4), 415-433. doi: https://doi. org/10.1177/107769905303000401

Wechsler, D. (2004). WAIS-III: Escala de Inteligência Wechsler para adultos. São Paulo: Casa do Psicólogo. 
Wechsler, D. (2013). WISC-IV: Escala Wechsler de Inteli-

Recebido em: 20/07/2018 gência para crianças: manual técnico. São Paulo: Casa do Reformulado em: 27/11/2018 Psicólogo. Aprovado em: 14/12/2018

Wechsler, D. (2014). WASI - Escala Wechsler Abreviada de Inteligência. São Paulo: Casa do Psicólogo.

About the authors:

Katya Luciane de Oliveira: Associate Professor at the Department of Psychology and Psychoanalysis/UEL, at the Master's and Doctoral Research Program in Education/UEL, and at the Master's Program in Psychology/UEL. CNPq Research Fellow.

E-mail:katyauel@gmail.com

ORCID: orcid.org/0000-0002-2030-500X.

Angélica Polvani Trassi: Psychologist. M.Sc. in Education from the Universidade Estadual de Londrina. Specialist in Psychological Assessment from Centro Universitário Filadélfia.

E-mail: angelica.polvani@gmail.com.

ORCID: https://orcid.org/0000-0001-6257-3857

Amanda Monteiro Inácio: Psychologist. Psychology Doctoral student at Universidade São Francisco in the field of Assessment in Psychology Education. M.Sc. in Education from Universidade Estadual de Londrina.

E-mail: amandalmonteiroo@gmail.com

ORCID: https://orcid.org/0000-0003-1892-6242

\section{Contact:}

Universidade Estadual de Londrina

Estrutura Administrativa

Rodovia Celso Garcia Cid, Pr 445 Km 380, Campus Universitário

Cx. Postal 10.011

Londrina-PR, Brasil

CEP: 86057-970 